\title{
A framework for comparative institutional research on HRM
}

Article

Accepted Version

Gooderham, P. N., Mayrhofer, W. and Brewster, C. (2019) A framework for comparative institutional research on HRM. The International Journal of Human Resource Management, 30 (1). pp. 5-30. ISSN 1466-4399 doi:

https://doi.org/10.1080/09585192.2018.1521462 Available at https://centaur.reading.ac.uk/79851/

It is advisable to refer to the publisher's version if you intend to cite from the work. See Guidance on citing.

To link to this article DOI: http://dx.doi.org/10.1080/09585192.2018.1521462

Publisher: Informa UK Limited

All outputs in CentAUR are protected by Intellectual Property Rights law, including copyright law. Copyright and IPR is retained by the creators or other copyright holders. Terms and conditions for use of this material are defined in the End User Agreement.

\section{www.reading.ac.uk/centaur}

\section{CentAUR}

Central Archive at the University of Reading 
Reading's research outputs online 


\title{
A COMPARATIVE INSTITUTIONAL RESEARCH AGENDA
}

\section{FOR HRM}

\begin{abstract}
:
This paper argues that institutional context has been singularly lacking in the most influential areas of human resource management (HRM). This lack of context has resulted in findings lacking in external validity. We present a research framework embedded in institutional theories. Thereafter, we draw on findings from comparative HRM research that underpins the framework.
\end{abstract}

Key words: HRM and context; HRM and time; stakeholder view of HRM; future HRM research; contextual framework of HRM

This research did not receive any specific grant from funding agencies in the public, commercial, or not-for-profit sectors. 


\section{INTRODUCTION}

Schuler and Jackson (2005) observed that the term 'personnel management' began to be replaced by the concept of 'human resource management' (HRM) from the mid-1970s. By the mid-1980s, HRM had largely displaced it not just as a concept employed by practitioners, but also as a subject of academic scholarship. The year 1984 is a particularly significant. In that year, two seminal books by Beer et al. (1984) and Fombrun et al. (1984) were published by authors from major schools in the USA offering original analyses of HRM (Beer et al, 2015). In simple terms Beer et al.’s framework included context, including national legislation and national industrial relations regimes, and argued that:

"HRM policies and practices are not and cannot be formed in a vacuum. They must reflect the governmental and societal context in which they are embedded. For this reason, policies and practices that work in the United States will not necessarily work in Europe or Japan” (Beer et al., 1984:34).

In contrast, Fombrun et al.'s (Devanna et al., 1984:35) framework ignored context and developed a firm-centric view of HRM: “...the firm must decide what optimal structure is needed to carry out its (performance) objectives."

We argue that much of the most influential HRM scholarship that has emerged since 1984 is aligned with Fombrun et al's notion of "strategic human resource management" rather than with Beer et al.'s more contextual approach to HRM. In short, we argue that HRM has become characterized by an unstated universalist assumption, and overlooks context. Further, we argue that neo-institutional theories - unavailable to Beer et al. in 1984 - offer a theoretically sufficiently developed and suitable mechanism for bringing context back in.

Our core argument in this review is as follows: the current status of HRM is one of 
research that is generally insensitive to developments in cross-national institutional theorization. Let us set out this argument in more detail. Although context was indicated in the Beer et al. model, context in its full sense was not adequately built into mainstream HRM research. We develop our core argument in three steps. We start by briefly reviewing HRM research and theorizing. Thereafter we present a Contextual Framework that is underpinned by comparative institutional theory. This framework provides a research agenda that emphasizes the need for a better theoretical understanding of the interplay between HRM and the broader context, using in particular neo-institutional theories. We support this approach by drawing on comparative HRM empirical research.

Before setting out, we have to clarify what we mean by HRM. There are two distinctive approaches to definitions of HRM. First, HRM is the process of managing people in organizations in a thorough, thought-through and structured manner (the meaning in the Beer et al., 1984, text). This, the more generic, definition, covers all the ways people are managed in different contexts. In this definition, all organizations have human resource management: Why and how they do it, and with what outcomes, are then the key questions. In the second definition, HRM is the process of managing people in organizations so as to maximize employee performance in order to meet the organization's objectives (the approach in the Fombrun et al., 1984, text). This, often referred to as Strategic HRM (SHRM), is more normative. In this definition, there would be many organizations that do not have HRM, although maybe they have personnel administration. Here the key questions would be about what was done and whether it led to improvements in employee performance and/ or organizational results. This is the definition that has dominated the HRM field. While the first definition takes a view that embraces context, Strategic HRM (Wright \& McMahan, 1992) has narrowed the field, restricting it to the activities of management in pursuit of 
organizational objectives, with the assumption that firm and managers have considerable autonomy to decide on strategy and take the appropriate actions. Context reminds us that those strategies and actions may be substantially constrained.

We adopt the first, wider definition, emphasizing developments that have taken place within comparative institutional theory as a way of understanding the variety of different ways in which people are managed. We are concerned with the relationship between context, organizations and the people that work for them.

\section{HRM and the Issue of Context}

The dominance of SHRM is borne out in terms of citations. Employing various combinations of 'HR', 'HRM' or 'human resource' in the title or subject, we conducted a search using Google scholar and the ISI database for the most highly cited articles between 1986 (allowing a couple of years for papers to get published and then cited) and 2014 (thirty years after the two classic texts). In Google scholar, we filtered for articles with 500+ citations during the chosen time-period. This led to 37 articles with the number of citations varying between 6,121 and 511. In ISI, we identified the 50 most cited articles based on numbers of citations in the Web of Science, ranging between 1,622 and 226. There was a substantial overlap between these sources. 22 articles are in both lists and 15/10 articles appear only in Google Scholar and ISI, respectively. Overall, most of these highly cited studies fall into the same stream, the impact of HRM on organizational performance, or, to a lesser extent, a second stream that deals with the influence of HRM on individual outcomes. Indeed, we found that 13 out of the 16 top most cited HRM papers deal with the impact of HRM on organizational performance. 
Overall, the broad SHRM finding is that effective HRM systems can have a positive, if small, effect on organizational performance (see e.g. Combs et al., 2006). Estimating the overall effect with any precision is problematic (Combs et al., 2006). One source of noncomparability is that the studies apply different HRM perspectives (Delery \& Doty, 1996). Further, even studies within the same perspective employ different HRM practices (Combs et al., 2006). Cross-sectional studies are typical in this area. This makes it difficult to be certain about the direction of causality (Paauwe \& Boselie, 2005) so that "the existing evidence for a relationship between HRM and performance should be treated with caution" (Wall \& Wood, 2005: 454; see also Wright et al. 2005).

However, even more striking is the US-centric aspect to this central stream of HRM research (Brewster et al., 2016). Of the 16 top most cited HRM papers, 12 sampled firms exclusively within the USA. We identified only one paper that drew on a firm sample outside of the USA and that was New Zealand (Guthrie, 2001). Findings are manifestly contextbound. There is no consideration of the impact of aspects of the institutional setting on organizational performance, for example the role of the state, employment regulation or trade unions. In short, there is a general lack of institutional context in the literature on the HRMperformance link. This remains the case even when we include newer, relatively highly cited studies such as Sun et al. (2007) and Chen and Huang (2009) that conducted their studies outside of North America.

This insensitivity to context is also a feature of the "subordinate" stream of outcomes research conducted at the individual level. One influential understanding of individual performance views it as a function of not just motivation but also of ability and opportunity: the so-called 'AMO' model (Boxall, 2003). Thus, Appelbaum et al. (2000) and Lepak et al. (2006) argue that HRM practices, or systems of practices, that are designed to impact on 
employee performance may be related to one or more of these three domains. Much of the research in this stream has been on highly proximal outcomes such as organizational commitment, motivation and job satisfaction (Jiang et al., 2012). While Jackson et al. (2014) conclude that there is strong evidence that effective HRM practices are associated with beneficial employee outcomes, some studies find either no or relatively small outcomes (Godard, 2010), or suggest that certain systems even create anxiety (Wood et al., 2012b) or job strain (Ramsay et al., 2000).

In general, the HRM and individual outcomes research area has focused on short-term effects with little research that takes into account longitudinal effects (Bowen \& Ostroff, 2004). Further, as Becker and Huselid (1998: 93) argued, one of the most important gaps in the HRM literature is "the absence of good empirical work" that links the levels of analysis from HRM systems through employee perceptions to firm performance. Recent research has begun to do that. For example, Van De Voorde et al. (2012) find broad support for 'mutual gains' with employers (organizational performance) and employees (perception of well-being) both benefiting from effective HRM; Jiang et al. (2012) use AMO to demonstrate an effectchain from HRM through proximal outcomes (employee motivation and human capital) to voluntary turnover and operational and financial outcomes. However, in common with organizational level SHRM, there is an absence of much sense of context in this stream of research. This may explain some of the varied findings. What works in HRM in one context may not be effective in another.

Despite the dominance of SHRM, clearly there are HRM studies beyond the prevailing stream. We observe streams of research that we label: 'HRM and industrial relations' 'comparative HRM'; 'international HRM'. All three are sensitive to context. Research linking HRM and industrial relations (IR) is particularly widespread in, but by no means limited to, 
the more unionized European continent (see Nienhüser \& Warhurst, 2012). It focuses on the role of institutionalized stakeholders outside and within the organization: Stakeholders such as the state that establishes legal regulations governing HRM, employers' associations, trade unions and works councils (Batt \& Banerjee, 2012; Kaufman, 2010b). Although in general, IR research has maintained a national focus with limited comparative work (Brewster, 2012), in detailing the workings of national systems of IR and in underscoring their lack of convergence (Brewster, 2012), the notion of a universal model of HRM has been subject to criticism (Björkman, Stahl \& Morris, 2012). There is a notion that national contexts differ in terms of stakeholders and regulatory complexity.

International HRM (IHRM) explores HRM in MNCs operating across national boundaries (Kaufman, 2014), although logically it could also include other organizations from the international not-for-profit sector, including governments, NGOs, and charities. A significant section of the IHRM literature addresses issues related to moving people across national borders (Black et al., 1992; Harzing \& Pinnington, 2015; Stahl et al., 2012). Whereas much of the expatriation literature has addressed cultural distance, another important strand of IHRM literature explores the way that institutional distance between countries constrain MNCs from adopting worldwide HRM policies. It is assumed in the majority of this literature (reflected in, for example, Dowling et al., 2013; Harzing \& Pinnington, 2015; Schuler et al, 1993; Stahl et al., 2012) that drives for consistency and world-wide policies in internationally operating organizations meet with national level restrictions, creating a "tension" between standardization and differentiation strategies (Kostova \& Roth, 2002:215). In short, in much of this literature there is a notion that national institutional settings matter for the transfer of HRM by MNCs. It has been argued that there may be a third driver, which follows the argument that there may be a dominance effect in HRM (Harzing \& Pinnington, 2015: $88 \mathrm{ff}$; 
Edwards et al., 2016). Since the demise of Japan as the exemplar in the 1980s, the USA has provided the dominant model. The notion is that the US management model appears to be being embraced by MNCs regardless of their home country origins as best suited to provide "the necessary flexibility to cope with rapidly evolving economic and technological conditions" and has thus become the de-facto "dominant" (or best practice) model (Pudelko \& Harzing, 2007: 539). However, contrary to this is the evidence that suggests that even US MNCs adapt their HRM practices to local institutional settings (Gooderham et al., 2006). Edwards and Rees (2011) speculate that this combination of pressures towards standardization, differentiation and dominance has resulted in various forms of hybridization of HRM practices in the subsidiaries of MNCs. Regardless, it is of note that so much of this strand of IHRM literature rests on comparative institutional distinctions (Edwards et al., 2016).

Comparative HRM (CHRM) looks for relationships across limited numbers of geographical settings (Lazarova et.al, 2008). Since 1990, the long-running Cranet project (www.cranet.org) has been a particularly important source of empirical CHRM studies (Dewettinck \& Remue, 2011; Gooderham \& Nordhaug, 2011). Two major sub-streams of research have emerged from Cranet. Primarily descriptive studies, triggered by academic interest and the need of businesses to better understand HRM across the globe, dominated the early stages of CHRM from around 1990. These continue and have expanded their scope, combining different numbers of countries/ regions and views of HRM and also adding a more explanatory perspective (Brewster \& Mayrhofer, 2012; Geringer, Frayne \& Milliman, 2002).

A second sub-stream of Cranet-based CHRM research looks at developments over time. The basic issue concerns whether HRM is converging to a joint template, or whether differences remain salient. Much of the convergence argument comes from rational actor 
models of the firm (e.g. Simon, 1955) and the world-polity approach (Meyer \& Rowan, 1977) arguing that actors are subject to isomorphic pressures to follow the Western model of rationalization. Cultural (e.g. Hofstede, 1980; House et al. 2004) and institutional (e.g. DiMaggio \& Powell, 1983; Hall \& Soskice, 2001) arguments favor divergence or, most often, the maintenance of differences. The empirical research is scarce. Rowley, Warner and colleagues (e.g. Rowley, 1997; Rowley \& Benson, 2002; Yeung, Warner \& Rowley, 2008) analyze developments in the Asian region and argue for bounded convergence in Asia. Cranet researchers (Brewster, Mayrhofer \& Morley, 2004; Mayrhofer, Brewster, Morley \& Ledolter, 2011) in Europe found little evidence of convergence.

The work on CHRM offers two major insights for a future HRM research agenda. First, context, particularly national context, is a significant, often primary, factor explaining observable commonalities and differences in HRM. Second, including time in studies of HRM is crucial because of potential insights not available from cross-sectional and static analyses.

We can also observe a stream of literature that has engaged with theory-building in HRM (Jackson et al., 2014; Wright \& McMahan, 1992). Whereas SHRM at the organizational level is underpinned by the resource-based view of the firm (RBV) (Allen \& Wright, 2007; Barney \& Wright, 1998; Boxall, 1996; McMahan, Virick \& Wright, 1999; Nyberg, Moliterno, Hale \& Lepak, 2014), its counterpart at the individual level has drawn on the behavioral approach (Jackson, 2013). To the extent that the HRM and the IR and IHRM streams have theoretical foundations, neo-institutionalism (e.g. Greenwood, Oliver, Suddaby \& Sahlin, 2008) is the emergent approach. Thus, these streams draw on insights into how formal and informal institutions affect organizations. This is even more the case for the CHRM stream. In the CHRM stream there is an assumption that informal institutions ("cultural elements - 
symbols, cognitive systems, normative beliefs - and the sources of such elements": Scott, 1987: 498), as well as formal institutions such as regulations ("to which individual organizations must conform if they are to receive support and legitimacy": Scott \& Meyer, 1983: 149) play a role. Wood et al., (2012a) report on the use of institutionalist thinking in comparative HRM. Likewise, this theoretical angle has been used in explaining the global diffusion of management practices (e.g. Lawler \& Hundley, 2008).

In the next section, we develop a framework for HRM research that takes into account context, not least institutional context. We argue that while employer and employee perceptions are precursors of behavior and HRM outcomes, both perceptions and behavior are conditioned not just by internal elements, but also by external contextual elements such as formal and informal institutions. Indeed these external contextual elements shape and condition internal elements. Our view is that institutional theory is required to enable HRM research to develop as a social science.

\section{A CONTEXTUAL FRAMEWORK OF HRM}

The Contextual Framework (figure 1) rests on a basic assumption. Management action in the HRM chain, the core of practical HRM activities, is nested within enabling and constraining forces that we refer to as institutions.

"Institutions are the rules of the game in a society or,., more formally, are the humanly devised constraints that shape human interaction... They can be either...formal constraints - such as rules that human beings devise -... (or) informal constraints such as conventions and codes of behavior." (North, 1990:3-4)

Institutions impact organizations so that management can maneuver only within relatively 
tight, externally located limits. Further, although there may be some convergence among leading industrial nations that trade with each other, an overwhelming feature is one of divergence (North: 1990). Hence, the concept of "varieties of capitalism" and the distinction between Liberal and Coordinated Market Economies (LMEs \& CMEs) (Hall \& Soskice, 2001) and the notion that across these, there are distinct national HRM regimes (Gooderham et al., 1999). Hence, a simplistic focus on the HRM chain and the strategy or policies of the firm misses important contextual factors. The Framework therefore challenges the (usually implicit) assumption, in particular in most variants of 'strategic' HRM and in the more individually focused elements of HRM research, that managements can choose and implement any strategy that they deem appropriate (Wangrow et al., 2015).

\section{FIGURE 1 ABOUT HERE}

The center of the framework is the HRM chain, consisting of strategy and policies, practices, and perceptions. The chain ends with the perceptions of various internal stakeholders (Nishii \& Wright, 2008), in particular employees, who experience management practices and transform them into behaviors which provide the link to outcomes.

Wolfgang: we need some clarity on what "HRM strategy" and "HRM policy" are. How are they different to "HRM Configuration"???

The chain operates both in internal and external contexts. We divide the internal context into two sub-contexts. The first of these is labeled Organizational Characteristics (Lawrence \& Lorsch, 1967; Thompson, 1967). This contains factors outside the HRM chain but within the organization. For example, size, technology, structure, or whether or not the 
organization is an MNC influence the configuration (the existence, role and structure of a specialist department) of the HRM function. The second, Internal Stakeholders, includes all individual and collective actors that have an interest in and are important for HRM, e.g. owners or shareholders, managers, representative bodies such as works councils and workforce members. Wolfgang: you need to mention "HRM Configuration" in this paragraph. In the Figure it sits beside Organizational Characteristics: how are these 2 related? Here is a suggestion:

A number of HRM scholars argue that "bundles", "systems" or "configurations of HRM practices impact firm performance to a greater degree than single HRM practices (e.g. Arthur 1992, 1994; Delery \& Doty, 1996; MacDuffie, 1995). Bae, J., \& Yu, G. C. (2005) argue that particular HRM configurations are a product of organizational characteristics such as whether the strategy is based on employee commitment or compliance (Walton, 1985). Managerial decisions on appropriate HRM configurations impact the HRM chain not least in determining the choice of HRM practices .

(I have to say that I find it odd that in the Figure HRM Configuration impacts HRM Strategy. Isn't it the other way round? So......

\section{Strong suggestion: Switch HRM Strategy \& Policies with HRM Configuration - it makes much more sense)}

The Outcomes of the HRM chain (Jiang et al, 2012) are located at different levels of social complexity. They include outcomes for the individual employee, e.g. job satisfaction or feelings of insecurity; for organizational HRM, e.g. recruitment success or functional flexibility; for organizational results, e.g. profitability or competitiveness; and for the country, e.g. investment in non-firm specific qualifications; and for world regions or the whole world, e.g. building capabilities. Different levels of outcome mutually influence each other. For example, efficient and successful recruitment impacts organizational outcomes such as costefficiency (saving money in recruitment) and strategic flexibility (through having appropriate staff). The likelihood of employee satisfaction is increased if individuals have a good match 
with their job. Outcomes also feed back to the HRM chain and the internal and external context; e.g., much employment legislation is a response to failures in the general practice of organizations. Wolfgang: The last 3 sentences should be supported by references.

Outcomes are mediated by the Perceptions of the Workforce. It is the workforce reaction and behaviors, rather than the espoused policies or the practices of individual managers, that leads to various kinds of outcomes (Nishii \& Wright, 2008). For example, women's reactions to discriminatory line management practices in the light of clear equal opportunity policies will be mediated by their individually and socially influenced perceptions of such action: in some societies, discrimination will be seen as objectionable, in others as 'negligible' or even 'normal'.

I do not see how the following emerges from the framework. There are no external stakeholders in the framework. "The perceptions of external stakeholders - pressure groups or the government - that are important for organizational legitimacy, may be influenced by the policies or the practices, and phenomena such as whistleblowing (Vandekerckhove \& Lewis, 2012) or employer review sites where current and former employees post critiques of organizations show that employees' perceptions can spill over into the public consciousness." I say "drop".

The framework incorporates Time (Jaques, 1982; George \& Jones, 2000; Sonnentag, 2012) in a threefold way. First, feedback loops from the HRM chain emphasize that any conceptual view on HRM has to include dynamic characteristics. Second, it differentiates between short and long term outcomes of HRM. For example, while budget cuts for training may boost financial indicators in the short run, they may hamper the long term development of the organization by reducing its strategic flexibility (ref). Third, the framework explicitly acknowledges that HRM is embedded in and evolves over time: Changes in the external 
context such as the rise or fall of labor unions, changes to labor law and economic development have a profound impact on the internal context (ref.). The variables of the Framework and their interplay will change over time. Wolfgang: could you add some supporting references.

While mainstream HRM research indicates that it is Organizational Characteristics and Internal Stakeholders (what about HRM configuration???) that have the most salient impact on HRM strategy and policies and HRM practices in the HRM chain, we argue that the External Context also has a significant impact on the HRM chain. We distinguish Formal and Informal institutions and argue that they set the framework within which the organization operates (Jackson \& Schuler, 1995).

The most influential stream of research we identified, SHRM, has its focus on the HRM chain and its immediate context: It is embedded in the organization. The prominence of the AMO-model and other individual and group centered theoretical views, of the resourcebased view, or the focus on the link between HRM and organizational performance, testifies to that. The broader context beyond the organization, and its interplay with HRM, has not received the same amount of attention or, we would argue, the amount of attention it deserves. Thus, our primary contribution to a future research agenda is located within the external context. By not fully taking into account the impact of established governance systems, labor markets, and systems such as those of education, fiscal regulation, competition and many others, an HRM-chain-only Input/ Output approach over-emphasizes the influence of the internal context.

Given the relative deficit of HRM research linking with the broader context, we call for additional conceptual and empirical work to more fully exploit advances in neoinstitutional theorizing and theory-building. This, we argue, will increase the impact of HRM 
by joining the efforts elsewhere to deal with the larger global questions the world faces. These are, of course, not complete blind spots in HRM research, and we note examples below, but they are areas where the marginal utility of HRM research efforts is largest.

\section{The Empirical Validity of the Framework}

Our Contextual Framework identifies a need for HRM research to accept the importance of context not just as a constraint, but also as essential to the field. Conceptualizing context requires defining a theoretical angle. The use of 'obvious' surface phenomena such as unemployment rates, quality of the educational system, etc. is important but has its limits. Unless we define what these elements represent in theoretical terms, understanding their importance for HRM will be difficult. Hoffman (1999: 351) states that:

"Institutional theory directs attention toward forces that lie beyond the organizational boundary, in the realm of social processes (Powell \& DiMaggio, 1991; Scott, 1995). A firm's action is seen not as a choice among an unlimited array of possibilities determined by purely internal arrangements, but rather as a choice among a narrowly defined set of legitimate options determined by the group of actors composing the firm's organizational field (Scott, 1991).”

Standard neo-institutional explanations of management practices and strategies predict limited diversity among firms that operate in the same industry or organizational fields within the context of a single society or national economy (Powell \& DiMaggio, 1991; Dobbin, Sutton et al., 1993). The field of comparative institutionalism accepts this insight but argues that acquiring and maintaining legitimacy is construed very differently across national settings. Analysts have attempted to link intra-organizational behavior with politics (Roe, 2003), political systems (Pagano \& Volpin, 2005), or legislation (Botero et al., 2003) but the 
most promising and to date widely used approach in HRM is the synthetic theories developed to include these and other national factors in explaining the differences between countries. Collectively these are known as comparative capitalisms theories (Jackson \& Deeg, 2008), with important contributions from Amable (2003); Hall \& Soskice (2001); Thelen (2014); and Whitley (1999) amongst others.

These theories contribute to the notion that the adoption of HRM practices is embedded in an external setting. Comparative institutionalist theory does not reject the notion of considerable variability at the firm level in terms of HRM. Agency remains significant (Gooderham et al., 2015). However, in moving beyond the internal context, it is able to expose that formal and informal institutions clearly do have an important impact on firm behavior.

One obvious barrier to conducting comparative institutional research on HRM is the need to have data covering a range of national settings (Farndale, 2010). Cranet has been able to overcome this barrier through its network of HRM researchers located at business schools located in more than 20 countries. Cranet has developed a common questionnaire that it has administered at approximately five yearly intervals since 1990. The questionnaire is mailed to the most senior HR manager in nationally representative samples of companies with more than 100 employees. Cranet has addressed potential comparability issues by intensive collaboration between researchers in the various relevant countries (Brewster et al., 1996; Parry et al., 2013).We review now a selection of Cranet findings that underscore the need to develop an HRM research agenda that adopts a comparative institutionalist perspective to external context. 


\section{Comparative HRM findings}

In terms of the Contextual Framework, Cranet research has shed light on the impact of national institutions and the significance of the comparative intuitionalist perspective in terms of: HRM Practices; HRM Configurations; Outcomes (at the firm-level); HRM Strategy and Policies and selected Internal Stakeholders. Cranet research has also combined the comparative institutionalist perspective with time and various HRM practices.

\section{The significance of national context on HRM practices}

One of the earliest Cranet studies (supplemented with other comparative data sets) to examine the impact of the external context on HRM practices was Schuler and Rogovsky's (1998) study. It focused on informal institutions and employed Hofstede's four cultural dimensions concerning variations in a range of HRM practices among European firms including, work-place child-care, pay-for-performance and focus on individual performance. Their results suggest that national culture provides an important explanation for the variance in the utilization of different compensation practices in different countries. For example, Schuler and Rogovsky's (1998:172) results specifically indicated that "individual incentive compensation practices have a better fit in countries with higher levels of Individualism", and in countries with low levels of Uncertainty Avoidance. Although, as Schuler and Rogovsky acknowledged, their research failed to control for a range of variables such as firm size and industry, all of which they conceded might explain a certain amount of variance in the use of these HRM practices, informal institutions have a pronounced impact on HRM practices.

Croucher et al. (2010) examined the impact of formal institutions on financial participation practices including share schemes, stock options and profit sharing. Of the three practices, they found that the use share schemes was significantly lower within firms located in CMEs. 
Berber et al. (2017) explore the influence of informal institutions to preferred approaches to various compensation practices utilized by organizations operating in the transition economies of CEE compared with those of western European countries. Using Hofstede's cultural dimensions, they find that cultural dimensions of power distance and individualism vs. collectivism are significant determinants of the usage of variable pay for managers. However, although culture has significant influence on management compensation, they observe variations from these dimensions. This could stem from firm-level effects but they also accept that their analysis failed to include in formal institutional factors. Brookes et al. (2011) found that formal institutional, and more specifically, labor relations factors, have more explanatory power of HRM practices than cultural factors. A similar conclusion is found in Farndale (2010) who simultaneously investigated the effects of external formal and informal context on HRM practices in $17 \mathrm{EU}$ countries while also controlling the effect of the European Union (EU) Social Charter. Her results indicated that formal institutional factors generally appear to have the strongest influence particularly concerning non-monetary benefits.

Goergen, Brewster and Wood (2009a) found that the relationship between firm level training and diverse corporate governance regimes broadly follows the formal institutional distinctions suggested by Amable (2003). Stronger shareholder rights in LMEs make for greater shorttermism, weaker tenure and a tendency towards the downsizing of workforces (Gospel and Pendleton, 2005: 14). Firms are more likely to invest in specific types of training and development where security of tenure is stronger, aimed at the development of knowledge in organizational specific processes and techniques. Peretz and Rosenblatt (2011) examined cultural influences as measured by GLOBE (House et al., 2004) on investment in training. While they found that internal context organizational characteristics factors such as size and 
technology are determinats of investment in training, they also found that low power distance, high future orientation, and high uncertainty avoidance were also significant predictors of increased investment in training. They argue that their results lend credence to the notion that management is significantly influenced by the external cultural or informal context.

\section{The significance of national context on HRM configuration}

The HRM “configurational approach" (e.g. Cappelli \& Neumark, 2004; Delaney \& Huselid, 1996; Lepak \& Snell, 2002) is concerned with the internal consistency of the organization's HRM policies or practices and views certain tightly coupled systems or 'bundles' of aligned HRM practices (rather than single practices) as enhancing organizational performance. However, configurational studies have employed different practices (Paauwe, 2009). One approach within Cranet research has been to develop Walton's (1985) distinction between control- and commitment-oriented approaches to management. Gooderham \& Nordhaug (1999) distinguished calculative and collaborative configurations of HRM and observed powerful country effects on the adoption of these. For example, whereas firms in Scandinavian countries focused on collaborative HRM, firms in the UK were much more likely to employ calculative HRM.

Gooderham et al. (2015) extended this analysis by distinguishing the impact of formal and informal institutions on the use of calculative configurations of HRM that they label as individualized pay-for-performance (I-PFP) schemes. Employing a multilevel analysis of over 4,000 firms in 26 countries, they explored determinants of I-PFP adoption. At the country level, they distinguished between cultural and institutional (labor regulation institutions) influences. At the firm level, they distinguished firms that view human resources as 
strategically important and firms that are foreign-owned. On the one hand, they observed that senior manager agency counts. On the other hand, their findings indicated that both cultural and institutional effects at the country level significantly influence the adoption of I-PFP.

\section{The significance of national context on the impact of HRM on outcomes}

A driving force behind the emergence of HRM was the belief that HRM practices should enhance organizational performance, not least in financial terms (Schuler and Jackson 2005). Gooderham et al. (2008) examined the extent to which configurations of HRM practices have a significant impact on firm performance with the latter measured as the perception that gross revenue over the past three years has been well in excess of costs or not. Deploying factor analysis on as many as $60 \mathrm{HRM}$ practices contained in the Cranet data set, they identify six bundles of calculative practices, six bundles of collaborative practices and three "intermediary" bundles.

Their findings both support and cast some doubt on the value of HRM for firm performance in the context of Europe showing differences between calculative and collaborative HRM. While they found that calculative and intermediary HRM bundles, with exceptions, generally have some impact on the performance of European firms, collaborative HRM bundles do not. Further, they observed that for European firms the country of location is a relatively important source of variation in performance. This was ascribed to differences in national economic cycles; but they also speculated that country of location may reflect the efficacy of national business systems. The authors argued that future studies should be designed to differentiate between cyclical economic conditions and long-term institutional conditions. This would require a longitudinal design ideally with several time points and combining macro-economic data together with organizational level data. 
Rizov and Croucher's (2009) study of HRM and performance in European firms is in one significant way commensurate with that of Gooderham et al. (2008) in that they also adopt the calculative/collaborative HRM dichotomy. However, unlike Gooderham et al. who differentiated between various bundles of calculative and collaborative HRM, Rizov and Croucher used only two composite HRM measures. Another difference is that Rizov and Croucher's self-reported measure of firm performance is significantly broader being a composite index comprised of five partial measures: service quality, level of productivity, profitability, product to market time and rate of innovation. However, despite these differences, when Rizov and Croucher tested the relationship between HRM practices and firm performance, their findings were similar to those of Gooderham et al. They found that while calculative HRM has a positive impact on performance, collaborative HRM has no effect.

However, Rizov and Croucher then inter-acted the two HRM measures with country dummies. Generally, they found no significant interaction effects of country and calculative practices. Instead, their analysis indicated positive interaction effects of collaborative practices for several CME countries including France, Germany and Denmark. However, their analysis also indicated no such effects for several other CME countries such as Belgium, Austria and Norway. This assortment of findings was also the case when Rizov and Croucher tested for other outcomes such as absenteeism and employee turnover. Overall, they concluded that collaborative HRM is more likely than calculative HRM to enhance firm performance when one takes into account the institutional setting. In short, firms located in high trust CME countries are more conducive to generating performance effects from collaborative HRM than in LME countries such as the UK. On this basis Rizov and Croucher 
(2009:18) argued that their findings "demonstrate that the CME model is superior (to the LME one) in supporting productive efficiency at the organizational level.”

Taken together, and allowing for differences in operationalizations of firm performance, both studies by Gooderham et al. and Rizov and Croucher indicate that the effect of HRM on firm performance is actually somewhat limited. However, both studies indicate that country of location is a factor that influences firm performance. Rizov and Croucher's interaction analysis suggests that external context interacts with HRM configurations to impact performance. Apospori et al. (2008) report a similar finding for clusters of northern and southern European countries: they found that the link between HRM and performance appears to be different in different geographies.

\section{The significance of national context on HRM Strategy and Policies}

HRM strategy and policy are expression of the overall intentions of employers rather than single practices or configurations of practices. For example, Galanaki \& Papalexandris (2007) observed how outsourcing of HRM - i.e. having a third-party service provider or vendor supply an HRM activity - varies nationally. Den Dulk, Peters and Poutsma (2012) found that the work-family policies of European organizations were not only affected by organizational characteristics, but also by the formal institutional context in which organizations operate. Thus, for example, employers in social-democratic and postcommunist regimes adopted fewer additional childcare and leave arrangements than employers in other regimes.

In the HRM literature, direct involvement has been regarded as a core universal HRM policy that cuts through "excessive layers of bureaucracy, challenging unilateralism, 
promoting trust and resolving problems before they compound themselves, allowing employees and managers to work together more harmoniously" (Brewster et al., 2014:795). Brewster et al. (2014) show that for Europe, while controlling for inter alia firm size, direct involvement is generally much more of a feature of CME countries than the LME country, the UK.

\section{The significance of national context on internal stakeholders}

Unsurprisingly, Goergen, Brewster and Wood (2009b) find that the strongest indicator of union strength was national legal tradition and that Brewster, Wood and Goergen (2015) find that firms located in LMEs are more likely to have neither collective bargaining nor works councils. In other words, formal institutional context has an impact on union recognition. However, in addition Brewster et al. (2015) explored the association between unionization and the critical issue of security of tenure. Overall, they find that if a decrease of the workforce is called for this is more likely to be done by softer policies (i.e. voluntary redundancies) rather than harder policies (i.e. compulsory redundancies) in firms with collective bargaining and works councils. Because of the preponderance of these in CME countries, national context is significant not just for representative bodies but also for workforce members. Using Amable's five-archetype model Croucher et al. (2012) arrived at broadly similar findings. However, they do indicate that categorizations of countries have limitations and that in-depth country-by-country analysis is important. For example, in the context of Scandinavia, Denmark has diverged because of its policy of flexicurity. Thus, despite high levels of unionization in terms of turnover it is more like a market-driven economy. 
Another stakeholder issue that Cranet research has addressed is the management location of the responsibility for HRM decision making. In particular, it has examined the influence role of the HR department in relation to line managers. Gooderham et al. (2015) analyzed 2335 indigenous organizations in 21 countries. They found not only firm level influences but also significant national level influences. At the firm level, they found that where the HR function has higher power, devolution is less likely. At the national level, devolution of decision making to line management is more likely in societies with more stringent employment laws and lower power distance. Thus, both formal and informal institutions influence the role of the HR function. Working with the same data set and with a focus on formal institutions, Brewster et al. (2015) arrived at similar conclusions observing that organizations in LME countries are the least likely to assign responsibilities for HRM to the line.

Another study of how national context influences internal stakeholders is Baour et al.'s (2008) study of the influence of societal factors on the strategic integration of female HR directors. Their results indicate that national environments that are characterized by enabling social policy practices are important for understanding differences in the strategic integration of female HR directors. Thus, in countries with a greater amount of enabling social policy practices such as Sweden and France as opposed to the UK or the US, female HR directors show a higher level of strategic integration.

\section{The significance of national context and time on HRM practices}

Institutional theory assumes that while change does take place over time, the national "rules of the game" evolve slowly. Despite the latitude that firms have for making strategic 
decisions, Cranet studies generally confirm this assumption. While Morley et al. (1996) observed some signs of convergence in relation to industrial relations and Gooderham and Brewster (2003) found a degree of Americanization of HRM, both studies emphasized continuing significant national differences. Likewise, Larsen and Brewster (2003) examined the decentralization or delegation of HRM responsibilities to the line management over a tenyear period. Their findings indicate no significant convergence in the relative positions of the countries they analyzed. Brewster, Croucher, Wood, and Brookes (2007) used longitudinal Cranet Survey data from Britain, Germany and Sweden to examine whether any convergence towards individual forms of employee voice mechanisms had taken place. Their hypothesis that a development from collective towards individual voice mechanisms is taking place, that is, a development towards convergence with the LME model, was largely rejected. They concluded that collective voice remains significant in large work organizations. In regards to national training systems, Goergen et al. (2012) find that despite adaptations to changing external circumstance, differences remain persistently distinct. Overall, Cranet data indicates that while there is evidence of directional similarity - practices increasing or decreasing in the same way across the countries - there is no evidence of final convergence - countries becoming more alike in the way they manage people (Mayrhofer et al., 2011).

\section{Conclusions}

HRM as an academic discipline is no longer 'new'. It has made huge strides and our understanding is vastly greater than it was more than three decades ago. For the future, we are suggesting that HRM needs to adopt a theoretically well-founded view of HRM in a multi- 
level context, serving multiple stakeholders and recognizing the importance of time. Our literature review and the corresponding Contextual Framework leads us to argue that a future HRM research agenda should give special emphasis to external contexts and that these are best conceptualized by institutional theory. Using Cranet research, we have validated the impact of the external context on the internal context.

In order to develop further as a field and to have a greater societal impact, HRM research has to get a better understanding of facets and levels of context and how they influence, and are influenced by, HRM. This will help to avoid an insular view of the firm and a 'one-size-fits-all' approach. In this respect, our call is for an extension of the recent debates on multi-level research in HRM (Lengnick-Hall \& Aguinis, 2012) to extend further to incorporate context. Although much of the Cranet literature we have drawn on has found distinctive effects for the main-stream operationalizions of formal and informal institutions, Goergen, Brewster and Wood (2013) have called for further refinement of these conceptualizations.

Well-crafted institutional conceptualizations of context have a particular advantage: They allow the development of theoretically guided analyses of the interplay between contextual elements at various levels and HRM. This is, we would argue, the most important aspect of this area of the future research agenda. Similar to the insight gained during the HRM-performance debate, it seems plausible that certain complex configurations of contextual factors rather than single, simple ones are of central importance. We argue that configurations of contextual elements at different levels of social complexity constitute powerful explanators for HRM and may be more important for our understanding and for HRM practice than organization's HRM strategies. Binding them together in a theoretically consistent way would allow HRM scholarship to progress greatly and establish a more 
comprehensive understanding of HRM processes and outcomes.

Finally, one challenge that will have to be met is that while some attention has been paid to Korea, Japan and some former Soviet-bloc countries, comparative institutionalist theory is primarily located within the context of the WEIRD (western, educated, industrialized, rich, developed) countries (Henrich, Heine \& Norenzayan, 2010). Characteristic of these are well-established powerful institutions such as the state, employers' associations, and labor unions. This is precisely the context of HRM these past thirty year and it ignores radical changes in the global location of economic activity as value chains have become disaggregated. A substantial proportion of the 'global factory' comprises outsourcing of labor-intensive activities by western MNEs to independent suppliers in emerging and/ or developing countries characterized by "institutional voids" - that is "a lack of regulatory systems and contract-enforcing mechanisms” (Miller et al., 2009:803). Buckley \& Strange (2015: 245) observe that "there is a substantial literature...highlighting low wage levels, poor working conditions and environmental abuses by the suppliers of various infamous lead firms (e.g. Nike, Apple)." Political power is concentrated in the hands of small elites that have no interest in establishing strong institutions. If HRM is to advance beyond its parochial, western enclave this particular external context must be embraced. Thus, there is a need to develop new and much broader approaches to conceptualizing cross-national institutional differences (Fainshmidt et al. 2016). Some progress has been made: e.g. Rowley and Benson's (2004) study of the Far East and Elvira and Davila's (2005) study of Latin America. However, there remains ample scope for HRM studies located in institutional voids. 


\section{REFERENCES}

Allen, M., \& Wright, P. (2007). Strategic management and HRM. In P. Boxall, J. Purcell and P. Wright (Eds.), The Oxford handbook of human resource management (pp. 88-107). Oxford: Oxford University Press.

Amable, B. (2003). The Diversity of Modern Capitalism. Oxford: Oxford University Press.

Apospori, E., Nikandrou, I., Brewster, C., \& Papalexandris, N. (2008). HRM and organizational performance in northern and southern Europe. The International Journal of Human Resource Management, 19(7), 1187-1207.

Appelbaum, E., Bailey, T., Berg, P., \& Kalleberg, A. (2000). Manufacturing advantage: Why high performance work systems pay off. Ithaca, NY: Cornell University Press.

Arthur, J. B. (1994). Effects of human resource systems on manufacturing performance and turnover. Academy of Management Journal, 37, 670-687.

Bae, J., \& Yu, G. C. (2005). HRM configurations in Korean venture firms: resource availability, institutional force and strategic choice perspectives. The International Journal of Human Resource Management, 16(9), 1759-1782.

Barney, J. (1991). Firm resources and sustained competitive advantage. Journal of Management, 17, 99-120.

Barney, J. B., \& Wright, P. M. (1998). On becoming a strategic partner: The role of human resources in gaining competitive advantage. Human Resource Management, 37, 31-46.

Batt, R., \& Banerjee, M. (2012). The scope and trajectory of strategic HR research: evidence from American and British journals. International Journal of Human Resource Management, 23, 1739-1762.

Becker, B. E., \& Huselid, M. A. (1998). High performance work systems and firm performance: A synthesis of research and managerial implications. In G. Ferris (Ed.), Research in Personnel and Human Resources Management: (pp. 53-101). Greenwich: JAI Press.

Beer, M., Boselie, P., \& Brewster, C. (2015). Back to the future: Implications for the field of HRM of the multistakeholder perspective proposed 30 years ago. Human Resource Management, 54, 427-438.

Beer, M., Spector, B., Lawrence, P. R., Quinn Mills, D., \& Walton, R. E. (1984). Managing Human Assets. The Groundbreaking Harvard Business School Program. New York: The Free Press.

Björkman, I., Morris, S., \& Stahl, G. K. (2012). Introduction. In G.K. Stahl, I. Björkman, I. \& S. Morris (eds), Handbook of Research in International Human Resource Management. Cheltenham: Edward Elgar. 1-12.

Black, J. S., Gregersen, H. B., \& Mendenhall, M. E. (1992). Global Assignments: Successfully Expatriating and Repatriating International Managers. San Francisco et al.: Jossey-Bass.

Botero, J. C., Djankov, S., La Porta, R., López de Silanes, F., \& Shleifer, A. (2003). The regulation of labor. Yale University, National Bureau of Economic Research, Working paper 9756.

Bowen, D. E., \& Ostroff, C. (2004). Understanding HRM-firm performance linkages: The role of the "strength" of the HRM system. Academy of Management Review, 29, 203-221.

Boxall, P. (1996). The strategic HRM debate and the resource-based view of the firm. Human Resource Management Journal, 6, 59-75.

Boxall, P. (2003). HR strategy and competitive advantage in the service sector. Human Resource Management Journal, 13, 5-20.

Brandl, J., Mayrhofer, W., \& Reichel, A. (2008). The influence of social policy practices and gender egalitarianism on strategic integration of female HR directors. The International 
Journal of Human Resource Management, 19(11), 2113-2131.

Brewster, C. (2006). Comparing HRM policies and practices across geographical borders. In G.K. Stahl, I. Björkman, I. \& S. Morris (eds), Handbook of Research in International Human Resource Management. Cheltenham: Edward Elgar, 68-90.

Brewster, C., Brookes, M., Johnson, P., \& Wood, G. (2014). Direct involvement, partnership and setting: a study in bounded diversity. The International Journal of Human Resource Management, 25(6), 795-809.

Brewster, C., Croucher, R., Wood, G., \& Brookes, M. (2007). Collective and individual voice: convergence in Europe? International Journal of Human Resource Management, 18(7), $1246-1262$.

Brewster, C., \& Hegewisch, A. (Eds.). (1994). Policy and Practice in European Human Resource Management. The Price Waterhouse Cranfield Survey. London, New York: Routledge.

Brewster, C., \& Mayrhofer, W. (Eds.). (2012). Handbook Of Research On Comparative Human Resource Management. Cheltenham: Edward Elgar.

Brewster, C., Mayrhofer, W., \& Morley, M. (Eds.). (2004). Human Resource Management in Europe. Evidence of convergence? Oxford: Elsevier/Butterworth-Heinemann.

Brewster, C., Gooderham, P. N., \& Mayrhofer, W. (2016). Human resource management: the promise, the performance, the consequences. Journal of Organizational Effectiveness: People and Performance, 3(2), 181-190.

Brewster, C., Tregaskis, O., Hegewisch, A., \& Mayne, L. (1996). Comparative research in human resource management: A review and an example. International Journal of Human Resource Management, 7: 585-604.

Brewster, C., Wood, G., \& Goergen, M. (2015). Institutions, unionization and voice: The relative impact of context and actors on firm level practice. Economic and Industrial Democracy, 36(2), 195-214.

Brookes, M., Croucher, R., Fenton-O'Creevy, M., \& Gooderham, P. (2011). Measuring competing explanations of human resource management practices through the Cranet survey: Cultural versus institutional explanations. Human Resource Management Review, 21(1), 68-79.

Brewster, C., Brookes, M., \& Gollan, P. J. (2015). The institutional antecedents of the assignment of HRM responsibilities to line managers. Human Resource Management, 54(4), 577-597.

Buckley, P. J., \& Strange, R. (2015). The Governance of the Global Factory: Location and Control of World Economic Activity. Academy of Management Perspectives, 29, 237249.

Cappelli, P., \& Neumark, D. (2004). External Churning and Internal Flexibility: Evidence on the Functional Flexibility and Core-Periphery Hypotheses. Industrial Relations: A Journal of Economy and Society, 43, 148-182.

Collins, C. J., \& Smith, K. G. (2006). Knowledge exchange and combination: The role of human resource practices in the performance of high-technology firms. Academy of Management Journal, 49, 544-560.

Combs, J., Liu, Y., Hall, A., \& Ketchen, D. (2006). How much do high-performance work practices matter? A meta-analysis of their effects on organizational pervormance.

Personnel Psychology, 59, 501-528.

Croucher, R., Brookes, M., Wood, G., \& Brewster, C. (2010). Context, strategy and financial participation: A comparative analysis. Human Relations, 63(6), 835-855.

Croucher, R., Wood, G., Brewster, C., \& Brookes, M. (2012). Employee turnover, HRM and 
institutional contexts. Economic and Industrial Democracy, 33(4), 605-620.

Delaney, J. T., \& Huselid, M. A. (1996). The impact of human resource management practices on perceptions of organizational performance. Academy of Management Journal, 39, 949-969.

Delery, J. E., \& Doty, D. H. (1996). Modes of theorizing in strategic human resource management: Tests of universalistic, contingency, and configurational performance predictions. Academy of Management Journal, 39 802-835.

Den Dulk, L., Peters, P., \& Poutsma, E. (2012). Variations in adoption of workplace workfamily arrangements in Europe: The influence of welfare-state regime and organizational characteristics. The International Journal of Human Resource Management, 23(13), 2785-2808.

Dewettinck, K., \& Remue, J. (2011). Contextualizing HRM in comparative research: The role of the Cranet network. Human Resource Management Review, 21(1), 37-49.

Devanna, M. A., Fombrun, C., \& Tichy, N. (1984). In C. J. Fombrun, N.M. Tichy, N. M. \& M.A. Devanna (eds.) A framework for strategic human resource management. Strategic Human Resource Management. New York: Wiley, 1984. 33-51.

DiMaggio, P. J., \& Powell, W. W. (1983). The Iron Cage Revisited: Institutional Isomorphism and Collective Rationality in Organizational Fields. American Sociological Review, 48: 147-160.

Dobbin, F., Sutton, J., Meyer, J. W., \& Scott, R. W. (1993). Equal opportunity law and the construction of internal labor markets. American Journal of Sociology, 99: 396-427.

Dowling, P. J., Festing, M., \& Engle Sr., A. D. (2013). International Human Resource Management $\left(6^{\text {th }}\right.$ ed.). London et al.: Cengage Learning EMEA.

Dunning, J. H., \& Lundan, S. M. (2008). Multinational Enterprises and the Global Economy. Cheltenham: Edward Elgar.

Edwards, T., \& Rees, C. (2011). International Human Resource Management: Globalization, national systems and multinational companies. Harlow: Pearson Education.

Edwards, T., Sánchez-Mangas, R., Jalette, P., Lavelle, J. \& Minbaeva, D. (2016) Global standardization or national differentiation of HRM practices in multinational companies? A comparison of multinationals in five countries. Journal of International Business Studies (online) 47: 997. doi:10.1057/s41267-016-0003-6

Elvira, M. M., \& Davila, A. (2005). Emergent directions for human resource management research in Latin America. International Journal of Human Resources Management, 16, 2265-2282.

Fainshmidt, S., Judge, W.K., Aguilera, R.V. \& Smith, A. (2016). Varieties of institutional systems: A contextual taxonomy of understudied countries. Journal of World Business, http://dx.doi.org/10.1016/j.jwb.2016.05.003

Fang, Y., Jiang, G.-L. F., Makino, S., \& Beamish, P. W. (2010). Multinational firm knowledge, use of expatriates, and foreign subsidiary performance. Journal of Management Studies, 47, 27-54.

Farndale, E. (2010). What is really driving differences and similarities in HRM practices across national boundaries in Europe? European Journal of International Management, 4(4), 362-381.

Fombrun, C. J., Tichy, N., \& Devanna, M. A. (Eds.). (1984). Strategic Human Resource Management. New York et al: Wiley. 
Galanaki, E., \& Papalexandris, N. (2007). Internationalization as a determining factor of HRM outsourcing. The International Journal of Human Resource Management, 18(8), $1557-1567$.

George, J., \& Jones, G. (2000). The role of time in theory and theory building. Journal of Management, 26, 657-684.

Geringer, J. M., Frayne, C. A., \& Milliman, J. F. (2002). In search of "best practices" in international human resource management: research design and methodology. Human Resource Management, 41, 5-30.

Godard, J. (2010). What is best for workers? The implications of workplace and human resource management practices revisited. Industrial Relations: A Journal of Economy and Society, 49, 466-488.

Goergen, M., Brewster, C., \& Wood, G. (2009a). Corporate governance and training. Journal of Industrial Relations, 51(4), 459-487.

Goergen, M., Brewster, C., \& Wood, G. (2009b). Corporate governance regimes and employment relations in Europe. Relations industrielles/Industrial relations, 64(4), 620640.

Goergen, M., Brewster, C., Wood, G., \& Wilkinson, A. (2012). Varieties of capitalism and investments in human capital. Industrial Relations: A Journal of Economy and Society, 51(s1), 501-527.

Goergen, M., Brewster, C., \& Wood, G. (2013). The effects of the national setting on employment practice: The case of downsizing. International Business Review, 22(6), 1051-1067.

Gooderham, P. N. (2007). Enhancing knowledge transfer in multinational corporations: a dynamic capabilities driven model. Knowledge Management Research \& Practice, 5(1), 34-43.

Gooderham, P. N., \& Brewster, C. (2003). Convergence, stasis or divergence? Personnel management in Europe. Beta - Scandinavian. Journal of Business Research, 17(1), $7-18$.

Gooderham, P., Minbaeva, D. B., \& Pedersen, T. (2011). Governance mechanisms for the promotion of social capital for knowledge transfer in multinational corporations. Journal of Management Studies, 48(1), 123-150.

Gooderham, P., Morley, M., Parry, E., Stavrou, E. (2015). National and firm level drivers of the devolution of HRM decision making to line managers. Journal of International Business Studies, 46(6), 715-723).

Gooderham, P., \& Nordhaug, O. (2011). One European model of HRM? Cranet empirical contributions. Human Resource Management Review, 21(1), 27-36.

Gooderham, P. N., Nordhaug, O., \& Ringdal, K. (1999). Institutional and rational determinants of organizational practices: Human resource management in European firms. Administrative Science Quaterly, 44, 507-531.

Gooderham, P., Nordhaug, O., \& Ringdal, K. (2006). National embeddedness and calculative human resource management in US subsidiaries in Europe and Australia. Human Relations, 59(11), 1491-1513.

Gooderham, P., Fenton-O’Creevy, M., Croucher, R., \& Brookes, M. (2015). A multilevel analysis of the use of individual pay-for-performance systems. Journal of Management, 0149206315610634.

Greenwood, R., Oliver, C., Suddaby, R., \& Sahlin, K. (Eds.). (2008). The SAGE Handbook of Organizational Institutionalism. London: Sage.

Gupta, A. K., \& Govindarajan, V. (2000). Knowledge flows within multinational 
corporations. Strategic Management Journal, 21(4), 473-496.

Guthrie, J. P. 2001. High-involvement work practices, turnover, and productivity: Evidence from New Zealand. Academy of Management Journal, 44(1): 180-190.

Hall, P. A., \& Soskice, D. (Eds.). 2001. Varieties of Capitalism. The Institutional Foundations of Comparative Advantage. Oxford: Oxford University Press.

Harzing, A.-W., \& Pinnington, A. (Eds.). (2015). International Human Resource Management, (4 ${ }^{\text {th }}$ ed.). London: Sage.

Henrich, J., Heine, S. J., \& Norenzayan, A. (2010). The weirdest people in the world? Berlin, Working Paper Series des Rates für Sozial- und Wirtschaftsdaten 139.

Hoffmann, A. (1999). Institutional evolution and change: Environmentalism and the U.S. chemical industry. Academy of Management Journal, 42, 351-371.

Hofstede, G. (1980). Culture's Consequences. International Differences in Work-Related Values. Newbury Park: Sage Publications.

House, R. J., Hanges, P. J., Javidan, M., Dorfman, P. W., \& Gupta, V. (Eds.). (2004). Culture, Leadership, and Organizations: The GLOBE Study of 62 Societies. Thousand Oaks, CAL.: Sage.

Huselid, M. A. (1995). The impact of human resource management practices on turnover, productivity, and corporate financial performance. Academy of Management Journal, 38, 635-672.

Ichniowski, C., Shaw, K., \& Prennushi, G. (1997). The effects of human resource practices on manufacturing performance: A study of steel finishing lines. American Economic Review, 87, 291-313.

Jackson, G., \& Deeg, R. (2008). Comparing capitalisms: understanding institutional diversity and its implications for international business. Journal of International Business Studies, $39,540-561$.

Jackson, S. E. (2013). Behavioral perspective of strategic human resource management. In E. H. Kessler (Ed.), Encyclopedia of management theory: (pp. 66-72). London: Sage.

Jackson, S. E., Renwick, D. W. S., Jabbour, C. J. C., \& Muller-Camen, M. (2011). State-ofthe-Art and Future Directions for Green Human Resource Management. Zeitschrift für Personalforschung, 25, 99-116.

Jackson, S. E., \& Schuler, R. S. (1995). Understanding Human Resource Management in the Context of Organizations and Their Environments. Annual Review of Psychology, 46, 237-264.

Jackson, S. E., Schuler, R. S., \& Jiang, K. (2014). An aspirational framework for strategic human resource management. Academy of Management Annals, 8, 1-56.

Jaques, E. (1982). The Form of Time. New York, London: Crane Russak, Heinemann.

Jiang, K., Lepak, D. P., Hu, J., \& Baer, J. C. (2012). How Does Human Resource Management Influence Organizational Outcomes? A Meta-analytic Investigation of Mediating Mechanisms. Academy of Management Journal, 55, 1264-1294.

Kalleberg, A. L., Nesheim, T., \& Olsen, K. M. (2009). Is participation good or bad for workers? Effects of autonomy, consultation and teamwork on stress among workers in Norway. Acta Sociologica, 52, 99-116.

Kaufman, B. E. (2010a). SHRM theory in the post-Huselid era: Why it is fundamentally misspecified. Industrial Relations, 49(2): 286-313.

Kaufman, B. E. (2010b). The theoretical foundation of industrial relations and its implications for labor economics and human resource management. Industrial and Labor Relations Review, 64 (1): 74-108. 
Kaufman, B. E. (Ed.). (2014). The development of Human Resource Management across Nations. Cheltenham: Edward Elgar.

Kostova, T., \& Roth, K. (2002). Adoption of an organizational practice by subsidiaries of multinational corporations: Institutional and relational effects. Academy of Management Journal, 45(1), 215-233.

Larsen, H. H., \& Brewster, C. (2003). Line management responsibility for HRM: what is happening in Europe? Employee Relations, 25(3), 228-244.

Lawler, J. J., \& Hundley, G. (Eds.). (2008). The global diffusion of human resource practices: institutional and cultural limits. Bingley et al.: JAI Press.

Lawrence, P. R., \& Lorsch, J. W. (1967). Organization and Environment: Managing Differentiation and Integration. Boston: Harvard University Press.

Lazarova, M., Morley, M., \& Tyson, S. (2008). International comparative studies in HRM and performance-the Cranet data: Introduction. The International Journal of Human Resource Management, 19(11), 1995-2003.

Lengnick-Hall, M. L. and H. Aguinis (2012). What is the value of human resource certification? A multi-level framework for analysis. Human Resource Management Review 22, 246-257.

Lepak, D. P., Liao, H., Chung, Y., \& Harden, E. E. (2006). A conceptual review of human resource management systems in strategic human resource management research. Research in personnel and human resources management, 25, 217-271.

Lepak, D. P., \& Shaw, J. D. (2008). Strategic HRM in North America: looking to the future. The International Journal of Human Resource Management, 19,1486-1499.

Lepak, D. P., \& Snell, S. A. (2002). Examining the human resource architecture: The relationships among human capital, employment, and human resource configurations. Journal of Management, 28, 517-543.

Luhmann, N. (1995). Social Systems. Stanford: Stanford University Press.

MacDuffie, J. P. (1995). Human resource bundles and manufacturing performance: Organizational logic and flexible production systems in the world auto industry. Industrial and Labor Relations Review: 48, 197-221.

Marchington, M. (2015). Human resource management (HRM): Too busy looking up to see where it is going longer term? Human Resource Management Review, 25, 176-187.

Marsden, D. (2004). Employment systems: Workplace HRM strategies and labour institutions. In B. E. Kaufman (Ed.), Theoretical Perspectives on Work and the Employment Relationship: (pp. 77-103). Champaign, Ill.: Industrial Relations Research Association.

Mayrhofer, W., Brewster, C., Morley, M., \& Ledolter, J. (2011). Hearing a Different drummer? Evidence of convergence in European HRM. Human Resource Management Review, 21, 50-67.

McMahan, G. C., Virick, M., \& Wright, P. M. (1999). Alternative theoretical perspectives for strategic human resource management revisited: Progress, problems and prospects. Research in Personnel and Human Resources Management, 4, 99-122.

Meyer, J. W., \& Rowan, E. (1977). Institutionalized organizations: Formal structure as myth and ceremony. American Journal of Sociology, 83, 340-363.

Miller, D., Lee, J., Chang, S., \& Le Breton-Miller, I. (2009). Filling the institutional void: The social behavior and performance of family vs non-family technology firms in emerging markets. Journal of International Business Studies, 40(5), 802-817.

Minbaeva, D., Pedersen, T., Björkman, I., Fey, C. F., \& Park, H. J. (2003). MNC knowledge transfer, subsidiary absorptive capacity, and HRM. Journal of International Business 
Studies, 34(6), 586-599.

Morley, M., Brewster, C., Gunnigle, P., \& Mayrhofer, W. (1996). Evaluating change in European industrial relations: research evidence on trends at organisational level. International Journal of Human Resource Management, 7(3), 640-656.

Nienhüser, W., \& Warhurst, C. (2012). Comparative employment relations: definitional, disciplinary and development issues. In C. Brewster and W. Mayrhofer (Eds.), Handbook of research on comparative Human Resource Management: (pp. 211-238). Cheltenham, UK; Northampton, MA: Edward Elgar.

Nishii, L. H., \& Wright, P. (2008). Variability within organizations: Implications for strategic human resource management. In D. B. Smith (Ed.), The people make the place: (pp. 225248). Mahwah, NJ: Lawrence Erlbaum Associates.

North, D. C. (1990). Institutions, Institutional change and Economic Performance. Cambridge: Cambridge University Press.

Nyberg, A. J., Moliterno, T. P., Hale, D., \& Lepak, D. P. (2014). Resource-based perspectives on unit-level human capital: A review and integration. Journal of Management, 40, 316346.

Ostroff, C., \& Bowen, D. E. (2000). Moving HR to a Higher Level: HR Practices and Organizational Effectiveness. In K. J. Klein and S. W. J. Kozlowski (Eds.), Multilevel Theory, Research, and Methods in Organizations: Foundations, Extensions, and New Directions: (pp. 211-266). San Francisco: Jossey Bass.

Paauwe, J. (2009). HRM and performance: achievements, methodological issues and prospects. Journal of Management Studies, 46, 129-142.

Paauwe, J., \& Boselie, P. (2005). HRM and performance: what next? Human Resource Management Journal, 15, 68-83.

Pagano, M., \& Volpin, P. (2005). The Political Economy of Corporate Governance. American Economic Review, 95, 1005-1030.

Parry, E., Stavrou, E., \& Lazarova, M. (2013). Introduction: Human resource management across time and context: Comparative research and global trends in HRM. In E. Parry, E. Stavrou, \& M. Lazarova (Eds.), Global trends in Human Resource Management: 1-11. London, UK: Palgrave Macmillan.

Peretz, H., \& Rosenblatt, Z. (2011). The role of societal cultural practices in organizational investment in training: A comparative study in 21 countries. Journal of Cross-Cultural Psychology, 42(5), 817-831.

Powell, W., \& DiMaggio, P. J. (Eds.). (1991). The new institutionalism in organizational analysis. Chicago: University of Chicago Press.

Pucik, V., Björkman, I., Evans, P., \& Stahl, G. K. (2015). Managing Knowledge in Multinational Firms. In A.-W. Harzing and A. H. Pinnington (Eds.), International Human Resource Management. Thousand Oaks et al.: Sage.

Ramsay, H., Scholarios, D., \& Harley, B. (2000). Employees and high-performance work systems: testing inside the black box. British Journal of Industrial Relations, 38, : 501531.

Roe, M. (2003). Political Determinants of Corporate Governance. Oxford: Oxford University Press.

Rowley, C. (1997). Conclusion: Reassessing HRM's Convergence. Asia Pacific Business Review, 3, 197-210.

Rowley, C., \& Benson, J. (2002). Convergence and Divergence in Asian Human Resource Management. California Management Review, 44, 90-109.

Rowley, C., \& Benson, J. (Eds.). (2004). The management of human resources in the Asia 
Pacific region: Convergence reconsidered. London: Frank Cass.

Rugman, A. M., \& Verbeke, A. (2001). Subsidiary-specific advantages in multinational enterprises. Strategic Management Journal, 22 237-250.

Rynes, S. L., Brown, K. G., \& Colbert, A. E. (2002). Seven common misconceptions about human resource practices Research findings versus practitioner beliefs. Academy of Management Executive, 16, 92-102.

Rynes, S. L., Giluk, T. L., \& Brown, K. G. (2007). The very separate worlds of academic and practitioner periodicals in human resource management: Implications for evidence-based management. Academy of Management Journal, 50, 987-1008.

Schuler, R., \& Jackson, S. E. (2014). Human resource management and organizational effectiveness: yesterday and today. Journal of Organizational Effectiveness: People and Performance, 1, 35 - 55.

Schuler, R. S., Dowling, P. J., \& De Cieri, H. (1993). An Integrative Framework of Strategic International Human Resource Management. Journal of Management, 19, 419-459.

Schuler, R. S., \& Jackson, S. E. (2005). A quarter-century review of human resource management in the US: The growth in importance of the international perspective. Management Revue, 16, 11-35.

Schuler, R. S., \& Rogovsky, N. (1998). Understanding compensation practice variations across firms: The impact of national culture. Journal of International Business Studies, 29(1), 159-177.

Scott, W. R. (1987). The Adolescence of Institutional Theory. Administrative Science Quarterly, 32, 493-511.

Scott, W. R. (1991). Unpacking institutional arguments. In W. Powell and P. DiMaggio (Eds.), The New Institutionalism in Organizational Analysis: (pp. 164-182). Chicago: University of Chicago Press.

Scott, W. R. (1995). Institutions and organizations: Ideas and interests. Thousand Oaks CA: Sage.

Scott, W. R., \& Meyer, J. (1983). The organization of societal sectors In J. W. Meyer and W. R. Scott (Eds.), Organizational Environments: Ritual and Rationality (pp. 129-153). Beverly Hills, CA: Sage.

Simon, H. A. (1955). A behavioral model of rational choice. The Quarterly Journal of Economics, 69, 99-118.

Sonnentag, S. (2012). Time in organizational research: Catching up on a long neglected topic in order to improve theory. Organizational Psychology Review, 2, 361-368.

Stahl, G., Björkman, I., \& Morris, S. (Eds.). (2012). Handbook of Research in International Human Resource Management (2nd ed.). Cheltenham, UK; Northampton, MA, USA: Edward Elgar

Thelen, K. (2014). Varieties of liberalization and the new politics of social solidarity. Cambridge: Cambridge University Press.

Thompson, J. D. (1967). Organizations in action. New York: McGraw-Hill.

Van De Voorde, K., Paauwe, J., \& Van Veldhoven, M. (2012). Employee well-being and the HRM-organizational performance relationship: A review of quantitative studies. International Journal of Management Reviews, 14, 391-407.

Vandekerckhove, W., \& Lewis, D. (2012). The Content of Whistleblowing Procedures: A Critical Review of Recent Official Guidelines. Journal of Business Ethics, 108, 253-264.

Wall, T. D., \& Wood, S. J. (2005). The romance of human resource management and business performance, and the case for big science. Human Relations, 58, 429-462.

Walton, R. E. (1985). From control to commitment in the workplace. Harvard Business 
Review, 63(2), 76-84.

Watson, T. J. (2010). Critical social science, pragmatism and the realities of HRM. International Journal of Human Resource Management, 21, 915-931.

Whitley, R. (1999). Divergent Capitalisms. Oxford: Oxford University Press.

Wood, G., Psychogios, A., Szamosi, L. T., \& Collings, D. G. (2012). Institutional approaches to comparative HRM. In C. Brewster and W. Mayrhofer (Eds.), Handbook of Research on Comparative Human Resource Management: (pp. 27-50). Cheltenham, UK: Edward Elgar.

Wood, S., Van Veldhoven, M., Croon, M., \& de Menezes, L. M. (2012). Enriched job design, high involvement management and organizational performance: The mediating roles of job satisfaction and well-being. Human Relations, 65, 419-445.

Wood, S. J., \& Wall, T. D. (2007). Work enrichment and employee voice in human resource management-performance studies. International Journal of Human Resource Management, 18, 1335-1372.

Wright, P. M., \& Boswell, W. R. (2002). Desegregating HRM: A Review and Synthesis of Micro and Macro Human Resource Management Research. Journal of Management, 28, 247-276.

Wright, P. M., Gardner, T. M., Moynihan, L. M., \& Allen, M. R. (2005). The relationship between HR practices and firm performance: Examining causal order. Personnel Psychology, 52, 409-446.

Wright, P. M., \& McMahan, G. C. (1992). Theoretical Perspectives for Strategic Human Resource Management. Journal of Management, 18, 295-320.

Yeung, A., Warner, M., \& Rowley, C. (2008). Guest editors' introduction. Growth and globalization: Evolution of human resource management practices in Asia. Human Resource Management, 47, 1-13. 


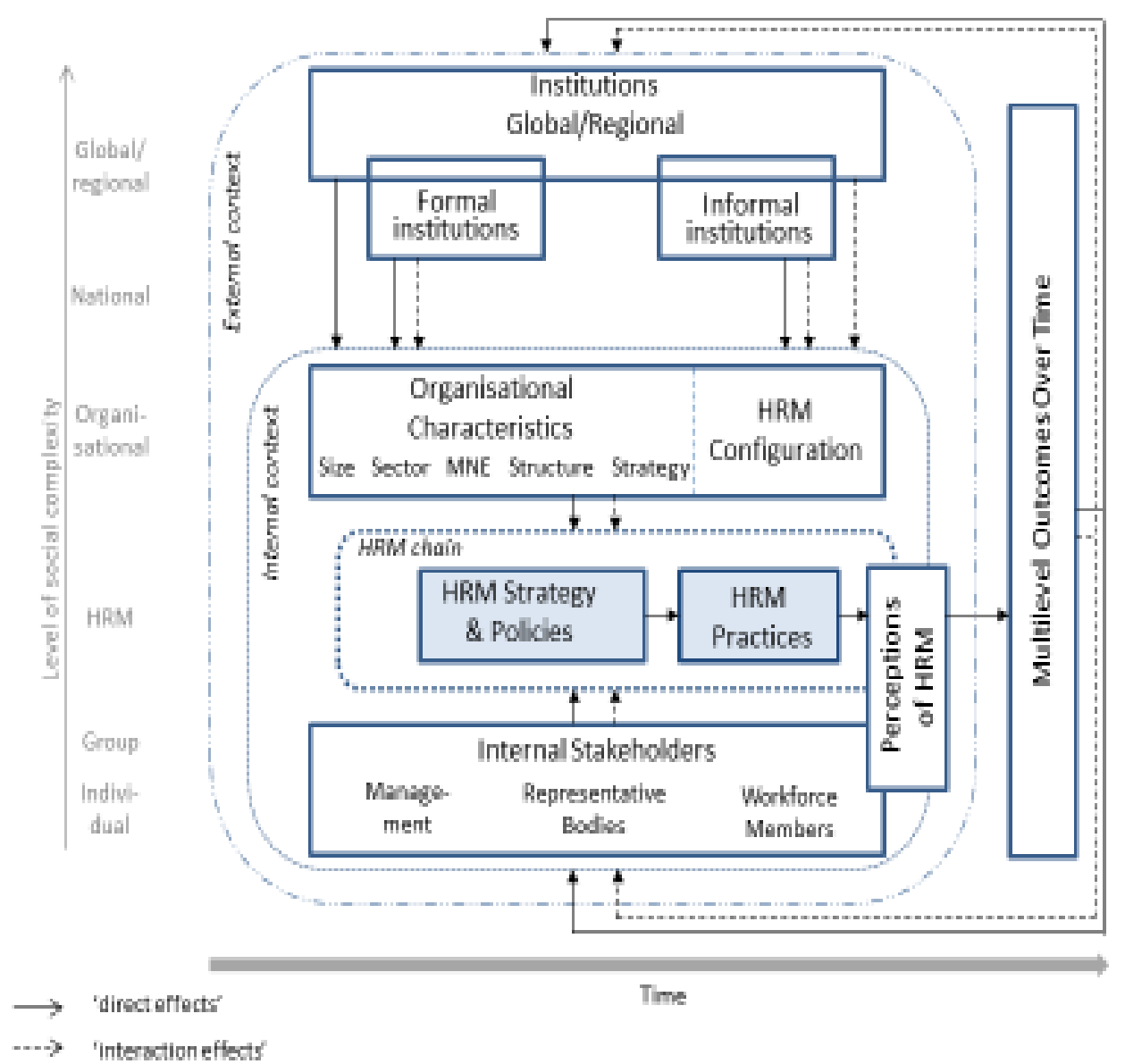

Figure 1: Contextual Framework of HRM 